\title{
The System of Temporal Adverbs in the French, German and Croatian Language
}

\author{
Assist. Prof. Dr. Tomislav Frleta \\ Department of French and Iberoromance Studies, University of Zadar, Croatia
}

Assoc. Prof. Dr. Anita Pavić Pintarić

Department of German Studies, University of Zadar, Croatia

\begin{abstract}
This paper aims to determine the typology and to compare the systems of temporal adverbs in the French, German and Croatian language. The approach proposed by Klum (1961) for the French language is used for the analysis of all three languages, in order to show the microstructure of the adverbs now and today. We argue that all three languages have developed very stable and very similar paradigms of temporal adverbs, which can be easily compared using Klum's approach. It will be shown that the paradigms differ only to some extent in the systematization of the representation of the period of the action.
\end{abstract}

Keywords: temporal adverbs, French, German, Croatian, system, time of the action

\section{Introduction}

The language system resides on three parameters/categories: person, time and space. Each of those three parameters has developed its own construction, paradigm and system. For example, most (Indo-European) languages have the paradigm of six persons (three for singular and three for plural). They all stand in relation to the first person $(I, M e$, Myself). Every person is defined to its relation to the first person, i.e. the second person would be the person that the first person talks to, the third person would be the person that the first (and the second person) talks about and so on.

The category of space has developed its own system that resides on the notion of "closeness" (to the first person). Therefore, the relation between the notion in space and the first person would be defined by the adverbs of space (here there).

The category of time is probably the most developed category of all. ${ }^{1}$ It marks the time when the action of the verb takes place. It can also mark the other notions such as repetition, duration, beginning of the action or frequency. However, the basic function of marking the time of the action is related to a person (the first person) and his/her position in time regarding the time of an action. Events are situated in time, and according to Klein (2009a: 32-33), can show the following relations: deictic (derived from the speech situation), anaphoric (mentioned in the preceding context), and calendar (given by some important event in history).

In this paper, we will compare the basic systems of temporal adverbs in French, German and Croatian, which denote the period of time ${ }^{2}$ of the action. It will be shown that adverbs, just like verbs, have a well elaborated system of temporal relations and that they are affected by the transposition of the action in the past or in the future. This will be visible in the analysis of different lexemes that indicate the time of the action. Each system rests on two main principles: firstly, it must have a certain number of mutually connected structures, and secondly, it must have a neutral starting point.

\section{Temporal adverbs}

\footnotetext{
${ }^{1}$ For more on concepts of time throughout history cf. Klein (2009a: 5-38).

2 In his book Verbe et Adverbe, Arne Klum uses French word époque which we translated as period (of the action).
} 
Temporal adverbs are, according to Klein (2009b: 40), "by far the richest class of temporal expressions, and in contrast to tense and aspect, they are found in all languages". They can be simple, like now, soon, often, morphologically compound like today, afterwards, and syntactically compound like long ago.

Temporal adverbs are traditionally divided according to logic and semantic criteria (time of action, duration of action, repetition of action, simultaneity, anteriority, posteriority).. ${ }^{1}$ Such a division has a positive side in detailed description but also a great drawback in the lack of systematics.

A slightly different approach was shown in the beginning of 1960 by the Swedish linguist Arne Klum. In his book on Verb and adverb (Verbe et adverbe) Arne Klum describes the system of the adverbs in French, that mark the time period (present, past and future). At the centre of this system is the adverb now (maintenant, jetzt, sada). This adverb represents the starting point of the system, and all other temporal relations for the periods are compared to this adverb.

In order to mark the different periods of time Arne Klum introduced the notion of the "vector" which directs the action towards the past or the future. In his theory, there are three types of vectors: PPOV (zero vector of the point of present), $\mathrm{PP}-\mathrm{V}$ (negative vector of the point of present) and PP+V (positive vector of the point of present). $\mathrm{OV}$ represents the present, the other two respectively represent the past and the future. PPOV regroups all three parameters of the language mentioned above (person - space - time): me - here - now (ego - hic - nunc; moi - ici - maintentnat; ich - hier - jetzt; ja - sada-ovdje).

Furthermore, Arne Klum claimed and showed that there is another system of temporal adverbs which is parallel to this one, where the central point is the adverb now. He therefore set a new adverb that represents the mirror point of the adverb now in the past or in the future, i.e. then (alors, dann, onda). ${ }^{2}$ Their starting point is the adverb then, and the vectors which direct the action from that adverb are PA-V, PA+V and PAOV (zero vector of the point of anteriority, which can be considered as an allocentric point because it refers to the adverb then which represents the transformation of now in the past or in the future).

\subsection{Temporal adverbs in French}

Temporal adverb system according to Arne Klum (adverbs representing the periods of time) is shown on French examples.

PP: now (maintenant)

\begin{tabular}{|l|l|l|}
\hline PP-V & PPOV & PP+V \\
\hline Past & Present & Future \\
\hline & maintenant & \\
\hline hier & aujourd'hui & demain \\
\hline
\end{tabular}

PA: then (alors)

\begin{tabular}{|l|l|l|}
\hline PA-V & PAOV & PA+V \\
\hline Past & Present & Future \\
\hline & alors & \\
\hline la veille & ce jour-là & le lendemain \\
\hline
\end{tabular}

These two basic tables representing the periods of time, differ only in their point of view of the time of the action. In the first table the moment of the action is related to the adverb maintenant (now, jetzt, sada) and represents "the moment of

\footnotetext{
${ }^{1}$ Klein (2009b: 65-67) gives four types of adverbs according to their function: temporal adverbs of position (they express relations BEFORE, AFTER, SIMULTANEOUS), temporal adverbs of duration, temporal adverbials of frequency, and temporal adverbials of contrast (still, already, again).

${ }^{2}$ Now is together with then time deictics because they both "convey a relationship between the time at which a proposition is assumed to be true, and the time at which it is presented in an utterance. In other words, now and then are deictic because their meaning depends on a parameter of the speech situation (time of speaking)." (Schiffrin 1987: 228).
} 
speaking" (le moment de la parole). The other table represents "the moment of (re)telling" (le moment du récit) i.e. the moment of the action that turns around the adverb alors (then, dann, onda).

From these basic parallel tables, all other relations in time can be set. Thus, Klum develops the relations including the days, weeks, months and years to show how the parallel systems work.

PP: now (maintenant)

\begin{tabular}{|l|l|l|}
\hline PP-V & PPOV & PA+V \\
\hline Past & Present & Future \\
\hline & maintenant & \\
\hline hier & aujourd'hui & demain \\
\hline la semaine dernière & en ce moment & la semaine prochaine \\
\hline le mois dernier & & le mois prochain \\
\hline l'année dernière & & l'année prochaine \\
\hline
\end{tabular}

PA: then (alors)

\begin{tabular}{|l|l|l|}
\hline PA-V & PAOV & PA+V \\
\hline Past & Present & Future \\
\hline & alors & \\
\hline la veille & ce jour-là & le lendemain \\
\hline la semaine précédente & à ce moment (-là) & la semaine suivante \\
\hline le mois précédent & & le mois suivant \\
\hline l'année précédente & & l'année suivante \\
\hline
\end{tabular}

These tables show the perfect parallelism and the coexistence of two paradigms of adverbs in the system of the French temporal adverbs.

Several things are to be noted:

Firstly, there is no lexeme that represents aujourd'hui in the PA. Instead, the explicative syntagm "demonstrative determiner + jour + là" is used.

Secondly, the difference in adjectives (dernier - précédent; prochain - suivant) represents the different point of departure: PP or PA, not the different time relation. Their relations in time are perfectly equal.

Thirdly, there is a small difference in usage of the preposition for indicating the present moment (en ce moment) and that same moment in the past (à ce moment(-là)). That difference (en vs. à) resides on the kinetic value of the prepositions. The preposition à refers to the point of arrival, the preposition de (non-mentioned here but completes the kinetic parallel structure together with the preposition à) refers to the point of departure, and the preposition en lacks the kinetic value, which makes it very suitable for expressing the present state (the state of non-movement).

This approach to the adverbs of time has its advantage in its systematics. It also shows the parallel systems, and the paradigms used to denote those systems.

\section{Temporal adverbs in Croatian and German}

In this chapter, the tables above are compared with Croatian and German.. The following results are obtained.

\section{Croatian}

PP: now (sada)

\begin{tabular}{|l|l|l|}
\hline PP-V & PPOV & PA+V \\
\hline Past & Present & Future \\
\hline & sada & \\
\hline jučer & danas & sutra \\
\hline
\end{tabular}




\begin{tabular}{|l|l|l|}
\hline prošlog tjedna $^{1}$ & u ovom trenutku / ovog trenutka & idućeg tjedna $^{2}$ \\
\hline prošlog mjeseca & & idućeg mjeseca \\
\hline prošle godine & & iduće godine \\
\hline
\end{tabular}

PA: then (onda)

\begin{tabular}{|l|l|l|}
\hline PA-V & PAOV & PA+V \\
\hline Past & Present & Future \\
\hline & onda $^{3}$ & \\
\hline dan prije & onog dana & sutradan (dan poslije) \\
\hline tjedan prije & u onom trenutku & tjedan poslije \\
\hline mjesec prije & & mjesec poslije \\
\hline godinu prije & & godinu poslije \\
\hline
\end{tabular}

Related to German, Klein (2001: 575-590) describes adverbs heute, gestern, morgen, which refer to a time interval, and vary in the art of reference to the time of speech. In the given context, heute refers to the day of speech, gestern refers to the day which precedes the day of speech, and morgen refers to the day following the day of speech. This is described by the "canonical meaning" of these three adverbs, which includes two components: a deictic one and a lexical one. Ehrich (1992: 108) describes temporal deixis as situative deixis (anteriority, posteriority and simultaneously; Vorzeitigkeit, Nachzeitigkeit and Gleichzeitigkeit) and calendarity (e.g. gestern, heute and morgen are calendary, whereas vorhin, momentan and gleich are not). Further on, Ehrich (1992: 110-117) discusses now (jetzt), which can refer to various periods of time. Jetzt can denote short-range actions, those which are recurrent or non-recurrent (Hans putzt sich die Zähne, Hans war jetzt beim Bäcker, Ich bringe Ihnen jetzt die Speisekarte), as well as those which are inevitable results of some processes (Meine Mutter ist jetzt alt. Bernstein und Karajan sind jetzt tot).

PP: now (jetzt)

\begin{tabular}{|l|l|l|}
\hline PP-V & PPOV & PA+V \\
\hline Past & Present & Future \\
\hline & jetzt & \\
\hline gestern & heute & morgen4 \\
\hline letzte Woche, vorige Woche & in diesem Moment & nächste Woche \\
\hline letzten Monat, vorigen Monat & & nächsten Monat \\
\hline letztes Jahr, voriges Jahr & & nächstes Jahr \\
\hline
\end{tabular}

PA: then (dann)

\begin{tabular}{|l|l|l|l|}
\hline PA-V & PAOV & & PA+V \\
\hline Past & Present & & Future \\
\hline & dann & & \\
\hline $\begin{array}{l}\text { am Vortag, den Tag } \\
\text { zuvor/vorher }\end{array}$ & an dem Tag; an diesem Tag & & $\begin{array}{l}\text { am Tag darauf, am } \\
\text { darauffolgenden Tag, am }\end{array}$ \\
\hline
\end{tabular}

1 There is a possibility to indicate the time with the adverb that is expressed with the noun in accusative, not only in genitive (prošli tjedan, prošli mjesec, prošlu godinu) which doesn't influence the meaning.

2 See the footnote 6 (idući tjedan, idući mjesec, iduću godinu). There is also a synonym for idući - sljedeći.

3 It is possible to replace the adverb onda with tada.

${ }^{4}$ Some German adverbs can be understood in the context, e.g. Morgens (jeden Morgen/every morning) war/ist er müde. Morgens (am Morgen des besagten Tages/on the morning of the day in question) fühlte er sich noch ganz gesund. (Duden Grammatik, 2016: 588). ${ }^{5}$ As Duden Grammatik (2016: 848) points out, adverbs of the type gestern, heute, morgen can be used with a noun as an adverb phrase, e.g. Der neue Staatspräsident will heute (Abend) eine Rede halten. Der Generalsekretär trifft morgen (Vormittag) in der Hauptstadt ein. 


\begin{tabular}{|l|l|l|l|}
\hline & & & nächsten Tag \\
\hline $\begin{array}{l}\text { in der Vorwoche, eine Woche } \\
\text { zuvor/vorher; vorherige Woche }\end{array}$ & in dem Moment & & $\begin{array}{l}\text { die Woche nachher, die } \\
\text { darauffolgende Woche, die } \\
\text { kommende Woche, die nächste } \\
\text { Woche }\end{array}$ \\
\hline $\begin{array}{l}\text { im Vormonat, einen Monat } \\
\text { zuvor/vorher, den vorherigen } \\
\text { Monat }\end{array}$ & & $\begin{array}{l}\text { den Monat nachher, den } \\
\text { nächsten Monat, den } \\
\text { darauffolgenden Monat, den } \\
\text { kommenden Monat }\end{array}$ \\
\hline $\begin{array}{l}\text { im Vorjahr, ein Jahr } \\
\text { zuvor/vorher; das vorherige Jahr }\end{array}$ & & $\begin{array}{l}\text { das Jahr nachher, das } \\
\text { daruffolgende Jahr, das nächste } \\
\text { Jahr, das kommende Jahr }\end{array}$ \\
\hline
\end{tabular}

\section{Discussion: now}

The tables show that the three compared languages have developed very similar mechanisms in describing the system of temporal adverbs.

It can be seen that all three languages have two different lexemes that indicate PP and PA (maintenant - alors; sada onda ${ }^{1}$; jetzt - dann) and that the lexeme that indicates the PA has a temporal meaning, whereas in context it can also obtain a conclusive meaning ("therefore") in the context. There are three different lexemes that indicate the present, the past and the future in all three languages (hier - aujourd'hui - demain; jučer - danas - sutra; gestern - heute - morgen).

Furthermore, it is visible that only French uses different adjectives to express the same time relation (one week ago, one month ago, one year ago) which refer to a different point of departure (PP or PA): dernier - précédent; prochain suivant; while in Croatian and German there is an adjective in PP and an adverb in PA: prošli - idući vs. prije - poslije; letzte - nächste vs. zuvor - nachher.

It is to be noticed that only German has the possibility of expressing the preceding day/month/year with derivations containing the prefix Vor- (before, preceding). French has a different lexeme (a noun) in the PA - la veille for expressing "the day before". In Croatian there are explicative syntagms such as dan prije (lit. "the day before"). It is also possible to say in French le jour d'avant, which also means "the day before".

In PA+V we find that French and Croatian have a special lexeme to say "the day after": le lendemain, sutradan, while in German, there are several explicative constructions am Tag darauf, am darauffolgenden Tag, am nächsten Tag but without the possibility of using one single lexeme.

German uses several different constructions to express the past or the next week, month or year. French and Croatian are limited only to one or two: la semaine dernière/passée; prošli/prethodni tjedan.

All three languages use systematically the same lexemes to transpose the action two days before or after the starting point: l'avant-veille, prekjučer, vorgestern („two days before“), le surlendemain, preksutra, übermorgen („two days after").

\section{Temporal adverb today}

If we apply the same approach to another paradigm of temporal adverbs, in which the starting point will be the adverb aujourd'hui ("today") instead of maintenant, we will obtain another list of systematically organized adverbs:

PP: aujourd'hui ("today")

\begin{tabular}{|l|l|l|}
\hline PP-V & PPOV & PA+V \\
\hline Past & Present & Future \\
\hline & (maintenant) & \\
\hline
\end{tabular}

1 In Croatian, there is a three-dimensional repartition of space and time (ovdje - tu - ondje; sada (ovda) - tada - onda) and in general of all relations expressed by any kind of deictic (ovakav - takav - onakav "this/that kind", ovuda - tuda - onuda "this/that way"). 


\begin{tabular}{|l|l|l|}
\hline (avant-hier) - hier & aujourd'hui & $\begin{array}{l}\text { demain - (après demain /le } \\
\text { surlendemain) }\end{array}$ \\
\hline hier matin & ce matin & demain matin \\
\hline hier soir & ce soir & demain soir \\
\hline hier dans la nuit & cette nuit & demain dans la nuit \\
\hline
\end{tabular}

PA: ce jour-là ("that day")

\begin{tabular}{|l|l|l|}
\hline PA-V & PAOV & PA+V \\
\hline Past & Present & Future \\
\hline & (alors) & \\
\hline le jour d'avant & ce jour-là & le jour d'après \\
\hline la veille au matin & le matin de ce jour-là & le lendemain matin \\
\hline la veille au soir & le soir de ce jour-là & le lendemain soir \\
\hline la veille dans la nuit & la nuit de ce jour-là & la nuit du lendemain \\
\hline
\end{tabular}

Again, some conclusions can be made based on the data from the table: there is a well-defined paradigm for temporal adverbs in the PP0. In this case the paradigm is not expressed by different lexemes but with the use of the demonstrative determiner - ce (cette) which means "this". The particularity lies in the fact that the determiner ce refers to the present day (today) only by leaving out the space adverb - là ("there"). If we use the space adverb là, the action is transposed to PA. Another particularity is that the day starts and ends with the night. So the adverb cette nuit ("this night") can mean both "last night" and "the night that is coming (at the end of today)". The only way to make a difference is to use a different tense: passé compose (past tense) for last night and present or future for the night that is coming.

In the PP-V and PP+V, there is the simple juxtaposition of the nouns matin and soir for indicating the part of the day. However, this does not apply to the noun night, which could be used in a prepositional group (dans/pendant la nuit) but it is not very likely that the good francophone will use such an expression to indicate that something happened yesterday during the night. It is more likely that hier soir ("yesterday evening") or some other explicative expression accompanied by a preposition will be used. ${ }^{1}$

The lack of the possibility to use *hier nuit ("yesterday night) could be the consequence of the "two nights" that surround the day.

When other points PAOV, PA-V and PA+V are analyzed, it can be seen that the further we go from the PP, the more explicative constructions we use.

There are differences in Croatian, at least for the PPOV.

PP: danas ("today")

\begin{tabular}{|l|l|l|}
\hline PP-V & PPOV & PA+V \\
\hline Past & Present & Future \\
\hline & (sada) & \\
\hline (prekjučer) - jučer & danas & sutra - (preksutra) \\
\hline jučer ujutro & jutros / danas ujutro & sutra ujutro \\
\hline jučer navečer & večeras /danas navečer & sutra navečer \\
\hline sinoć/jučer na noć / po noći & noćas / danas na noć / po noći & sutra na noć / po noći \\
\hline
\end{tabular}

1 The famous movie Saturday night fever is translated into French: La fievre du samedi soir. 
PA: onog dana ("that day")

\begin{tabular}{|l|l|l|}
\hline PA-V & PAOV & PA+V \\
\hline Past & Present & Future \\
\hline & (onda) & \\
\hline dan prije & onog dana & dan poslije \\
\hline dan prije ujutro & onog dana ujutro & sutradan ujutro \\
\hline dan prije navečer & onog dana navečer & sutradan navečer \\
\hline dan prije na noć / po noći & onog dana na noć / po noći & sutradan na noć / po noći \\
\hline
\end{tabular}

In the paradigm of the starting point (PPOV) danas ("today"), it is clearly visible that we deal with the systematic use of the Old Slavic demonstrative pronoun $\mathrm{sb}, \mathrm{si}$, se (m/f/n sg.), ${ }^{1}$ which is added as a suffix on all parts of the day in order to represent exactly "the morning, the evening or the night of the present day". That suffix is not possible in the PP-0 nor in the PP+V, as well as it is not possible in the PA. It means that the demonstrative pronoun was systematically used only for PPOV which is in the closest relation to the first person and the present moment.

It is also possible to use the explicative form with the indication of today (danas) and the agglutinated adverbs (preposition + noun) that mean "in the morning" (ujutro) or "in the evening" (navečer).

As in French, the further we go from the PP, the more explicative construction will be found in developing the time relations such as already mentioned: ujutro ("in the morning"), navečer ("in the evening").

In German, the adverbs related to heute and dann are the following.

PP: heute ("today")

\begin{tabular}{|l|l|l|}
\hline PP-V & PPOV & PA+V \\
\hline Past & Present & Future \\
\hline & (jetzt) & \\
\hline (vorgestern) - gestern & heute & morgen - (übermorgen) \\
\hline gestern Morgen & heute Morgen, diesen Morgen & morgen früh / morgen $^{2}$ \\
\hline gestern Abend & heute Abend & morgen Abend \\
\hline gestern Nacht/gestern in der Nacht & heute Nacht & morgen Nacht \\
\hline- & gestern Abend /letzte Nacht & - \\
\hline
\end{tabular}

PA: dann ("then"), an dem Tag ("that day")

\begin{tabular}{|l|l|l|}
\hline PA-V & PAOV & PA+V \\
\hline Past & Present & Future \\
\hline & dann & \\
\hline den Tag vorher & an dem Tag & \\
\hline den Tag zuvor am Morgen & an dem Morgen & (am) nächsten/folgenden Morgen \\
\hline den Tag zuvor am Abend & an dem Abend & (am) nächsten/folgenden Abend \\
\hline die Nacht zuvor & in der Nacht & nächste Nacht, in der nächsten Nacht \\
\hline
\end{tabular}

1 For more information on the Old Slavic demonstrative pronoun see: Matasović (2016) s.v. danas, or in Gluhak (1993) s.v. dan.

2 It is not possible to apply the same principle of the construction as in heute Morgen because of cacophony ( ${ }^{*}$ morgen Morgen), so the solution is to simply use morgen or, more frequently, morgen früh ("tomorrow early (in the morning)"). 
\begin{tabular}{|l|l|}
\hline- & gestern Abend, letzte Nacht \\
\hline
\end{tabular}

In German, the paradigm of the adverbs referring to the time of the day stands between the two analyzed systems (French and Croatian). It did not develop any special adverbs that mean "this morning or this evening". It rather uses a kind of an explicative syntagm that binds the adverb heute and the noun Morgen ("today morning"). The same construction is used for all other parts of the day. This way of marking various parts of the day resembles the Croatian system with the difference, that the Croatian uses the adverb danas (heute) and the agglutinated adverb ujutro (danas ujutro - heute Morgen).

The other possibility diesen Morgen reflects the only possibility in French (ce matin), also found in Croatian with the same elements (ovog jutra). All of them mean "this morning".

Once again, the further we go from the PPOV, the more explicative forms with the adjectives: last, passed, before are found.

\section{Conclusion}

The analysis shows that all three languages use very similar constructions to express the period of the action. They use either lexemes (aujourd'hui, danas, heute) or syntagms composed of noun/adverb and adjective or another adverb (la semaine dernière, le jour d'avant, prošli tjedan, dan prije, heute Abend). It is clearly visible that they all developed the same or at least very similar mechanism in denoting the relations in time.

Combinations vary from one language to another. In French adjectives (dernier, prochain) are used in marking the past or the future, while the present is expressed with the demonstrative (ce, cet, cette). French also shows the perfect minisystem of adverbs that turn around two main points: PP and PA (avant-hier - hier - aujourd'hui - demain - aprèsdemain; l'avant-veille - la veille - ce jour-là - le lendemain - le surlendemain).

Croatian uses adjectives with adverbs to express the past or the future (prošli/iduci tjedan) and shows almost the same systematics as French in transposing the moment of speaking to the moment of retelling with some explicative syntagms in PA (prekjučer - jučer - danas - sutra - preksutra; dva dana prije - dan prije - onaj dan - sutradan - dva dana poslije). On the other side, Croatian has a perfectly developed system in denoting the parts of the present day for PPOV (noćas - jutros - danas - večeras - noćas). This micro-system is due to the systematic use of the Old Slavic demonstrative pronoun $s b$, si, se, which is added as the suffix to a part of the present day: dan-as, jutro-s, večer- as, noćas. This suffix works also for the seasons: ljetos, jesenas, zimus, proljetos ("last summer, autumn, winter, spring).

German partly follows the French model in the way that it has Vortag as the expression for "the day before", whereas it uses explicative syntagms in denoting the future in both PP and PA. On the other hand, German has a possibility to directly bind adverb and noun in order to express the part of the day (heute Morgen, gestern Abend).

Finally, two parrallels can be drawn for all three languages. Firstly, all three languages have developed different lexemes to denote the present, the past and the future of the PP (aujourd'hui, danas, heute; hier, jučer, gestern; demain, sutra, morgen). Secondly, they all have the possibility to use the demonstrative pronoun/determiner to mark the specific part of the present day: ce matin, ovo jutro, diesen Morgen.

\section{Literature}

[1] Barić, E. et al. (1997). Hrvatska gramatika. Zagreb: Školska knjiga

[2] Duden. Die Grammatik (2016). Berlin: Bibliographisches Institut.

[3] Ehrich, V. (1992). Hier und jetzt: Studien zur lokalen und temporalen Deixis im Deutschen. Tübingen: Niemeyer.

[4] Gluhak, A. (1993). Hrvatski etimološki rječnik. Zagreb: August Cesarec.

[5] Imbs, P. (1968). L'emploi des temps verbaux en français moderne. Paris: Klincksieck.

[6] Klein, W. (2001). Deiktische Orientierung. In M. Haspelmath, E. König, W. Oesterreicher, \& W. Raible (Eds.), Sprachtypologie und sprachliche Universalien (pp. 575-590). Vol.1/1. Berlin: de Gruyter.

[7] Klein, W. (2009a). Concepts of time. In W. Klein, Ping Li (Eds.), The expression of time (pp. 5-38). Berlin, New York: Mouton de Gruyter. 
[8] Klein, W. (2009b). How time is encoded. In W. Klein, Ping L. (Eds.), The expression of time (39-81). Berlin, New York: Mouton de Gruyter.

[9] Klum, A. (1961). Verbe et adverbe. Uppsala: Almqvist and Wiksells.

[10] Matasović, R. (2008). Poredbenopovijesna gramatika hrvatskoga jezika. Zagreb: Matica hrvatska.

[11] Matasović, R. (2016). Etimološki rječnik hrvatskoga jezika. Zagreb: Institut za hrvatski jezik i jezikoslovlje.

[12] Menzel, T. (2008). Temporaladverbien oder Kasusfunktion: Der Instrumental der Zeit im Russischen, Polnischen und Serbischen/Kroatischen, In S. Kempgen, K. Gutschmidt, U. Jekutsch, L. Udolph (Eds.), Deutsche Beiträge zum 14. Internationalen Slavistenkongress Ohrid (pp. 263-275). München.

[13] Musulin, M., Macan, Ž. (2006). Usvajanje priloga u inojezičnome hrvatskom, Lahor, 2/2, 176-189.

[14] Raguž, D. (1997). Praktična hrvatska gramatika. Zagreb: Medicinska naklada.

[15] Riegel, M., Pellat, J -C., Rioul, R. (2004). Grammaire méthodique du français. Paris: PUF.

[16] Schiffrin, D. (1987). Discourse markers. Cambridge University Press.

[17] Silić, J., Pranjković, I. (2005). Gramatika hrvatskoga jezika za gimnazije i visoka učilišta. Zagreb: Školska knjiga.

[18] Šarić, Lj. (1999). Temporaladverbien im Kroatischen und die Theorie der generalisierten Quantifikatoren, Die Welt der Slaven, 44, 117-134.

[19] Vagasi, M. (1996). Relation entre adverbes de temps et temps verbaux, Revue d'Études Françaises, 1/1996, 101-109.

[20] Witczak, M. (2006). Wann ist jetzt?: das Lebensalter als Variable der Bedeutungszuweisung beim Verweis auf die subjektive Zeit; eine Untersuchung an deutschen Temporaladverbien. Frankfurt am Main: Peter Lang.

[21] Zifonun, G., Hoffmann, L., Strecker, B. (1997). Grammatik der deutschen Sprache. Berlin, New York: Walter de Gruyter. 